\title{
EFFECT OF 17- $\alpha$-METHYL TESTOSTERONE (MT) ON ALL-MALE SEX REVERSAL AND DETERMINATION, GROWTH AND SURVIVAL OF Clarias gariepinus JUVENILES IN CONCRETE STAGNANT SYSTEMS.
}

\author{
Robert, E.A. ${ }^{1}$, Ovie, S.O $^{2}$, Onyeche, V.O ${ }^{3}$ \\ ${ }^{1}$ National Institute for Freshwater Fisheries Research, New Bussa, Niger state, Nigeria; \\ ${ }^{2}$ National Institute for Freshwater Fisheries Research, New Bussa, Niger state, Nigeria; \\ ${ }^{3}$ National Institute for Freshwater Fisheries Research, New Bussa, Niger state, Nigeria;
}

Corresponding author: Robert, E. A; Email: ememrobert@gmail.com

DOI: $10.31364 /$ SCIRJ/v7.i8.2019.P0819691

http://dx.doi.org/10.31364/SCIRJ/v7.i8.2019.P0819691

\begin{abstract}
Sex determination, growth performance and survival of Clarias gariepinus juveniles were examined as they responded to 17- $\alpha$-methyl testosterone (MT) and absolute ethanol mixed in their feed. Varying levels of $50 \mathrm{mgKg}^{-1} / \mathrm{MT}, 100 \mathrm{mgKg}^{-1} / \mathrm{MT}$ and 0 $\mathrm{mgKg}^{-1} / \mathrm{MT}$ were used. These inclusion levels further served as treatments TCG 50, TCG 100, TCG 0. A total of 270 Clarias gariepinus juveniles were stocked in six (6) concrete stagnant systems of 2 metre by 2 metre square. Treatments were duplicated and TCG 0 served as the control. Duration was for One hundred and twenty one (121) days. The mean initial weights were taken as $0.05 \pm 0.00^{\mathrm{a}} \mathrm{g}$ for treatment TCG $0,0.06 \pm 0.01^{\mathrm{a}} \mathrm{g}$ for treatment TCG 50 and $0.05 \pm 0.00^{\mathrm{a}} \mathrm{g}$ for treatment TC 100 . Highest mean weight gain of $2.40 \pm 0.21^{\mathrm{b}} \mathrm{g}$ observed in the study was seen in the Clarias gariepinus juvenile tank TCG 50. Performance index showed treatment TCG 50 performed highest with value $116.02 \pm 0.00^{\mathrm{a}}$. Survival rate was highest in treatment TCG 0 with $92.22 \pm 1.57^{\mathrm{a}} \%$, higher in treatment TCG 100 with $83.33 \pm 7.86^{\mathrm{a}} \%$ and high in treatment TCG 50 with $81.11 \pm 1.57^{\mathrm{a}} \%$. Condition factor K was greater than 1 throughout the study showing well-being of the fishes; highest in treatment TCG 50 at value 6.67 . Water quality parameters were at normal ranges throughout the study.
\end{abstract}

Keywords: sex reversal, sex determination, growth, survival, duplicates, Clarias gariepinus, juveniles, stagnant.

\section{INTRODUCTION}

Hormones are important in fish farming because they have been known to increase production, making it possible for one sex of a specie to grow bigger and faster than the other sex. This technique used for increase in fish production based on sexual dimorphism uses hormones-androgens and estrogens. Androgens and estrogens must be handled with care therefore, and fish adequately managed to ensure success (Hoga et al.,2018).

Sex- reversal of fish to near all-male, involves the administration of a male androgen to recently hatched fry so that the undifferentiated gonadal tissue of generic female of that fish, develops testicular tissue, therefore functioning as males (Megbowon et al.,2009; Megbowon and Mojekwu, 2014) 
The use of hormones therefore, for sex-reversal treatments can be carried out successfully and commercially by immersion and application in fish diet. The immersion procedure has its doses affecting the efficiency of hormonal treatments along with other factors such as hormone type, exposure timeframe and water temperature, aiding its efficiency or lack thereof (Pandian and Sheela, 1995).

The addition of hormones in feed therefore, is considered more efficient since it is easily controlled while allowing for optimal dosage to sex-reverse completely all-male or all-female fishes (Piferrer, 2001). Scarcity of male broodstocks are on the high; many of the male broodstocks are observed having no matured testes, so the use of 17- $\alpha$-Methyl Testosterone (MT) in feed is necessary to determine increase in the viability of males (Robert et al., 2019b).

\section{MATERIALS AND METHODS}

This research served to determine the effect of 17- $\alpha$-Methyl testosterone (MT) on sex-reversal to near all-male, sex determination, growth and survival of Clarias gariepinus juveniles.

\section{Experimental Fish}

Fry were procured after induced breeding using Clarias gariepinus broodstocks. This induced breeding was carried out in the hatchery indoor unit of National Institute for Freshwater Fisheries Research New Bussa, Niger State of Nigeria.

\section{Experimental Water Source}

The source of water was NIFFR's Kigera Dam which supplies water all year round for fish breeding and management purposes; yet, often augmented with borehole systems during the dry season.

\section{Experimental Procedure}

Induced breeding using Clarias gariepinus broodstocks were carried out. After 7days, the fry were taken outdoor and 45 fry per tank were distributed evenly into six $2 \mathrm{~m} \times 2 \mathrm{~m} \times 1 \mathrm{~m}$ concrete stagnant tanks for all-male sex-reversal. The hormone $17 \alpha-$ Methyltestosterone (MT) was mixed with $4 \mathrm{ml}$ absolute ethanol orally, into fish feed in varying doses: $50 \mathrm{mg} / \mathrm{kg}$ and $100 \mathrm{mg} / \mathrm{kg}$, while the control were fed normal feed diet without the addition of $17 \alpha$-Methyltestosterone and absolute ethanol. There were three treatments replicated two times for the main treatments and the control treatment. These treatments were: TCG 50, TCG 100, TCG 0.

Fish feed was $0.7 \mathrm{~mm}$ NIFFR fry feed at stocking, $2 \mathrm{~mm}$ NIFFR feed in the first and second months and 4mm NIFFR feed in the third and fourth months. $17 \alpha$-Methyltestosterone (MT) and absolute ethanol were poured evenly on feed, mixed and dried under room temperature for twenty four (24) hours; and fish feeding was carried out at 5\%,5\%,3\% and 2\%, of the body weight of fish till end of the experiment when fry grew to juvenile stage. Sex determination to determine all-male sex reversal was carried out visually according to Viveen et al., (1985) from month 3 and sex reversal was clearly seen. There were 39 mortalities from stocking till end of the experiment. These mortalities were due to weather changes.

\section{Growth Parameters}

Growth parameters such as MIW, MFG, \%WG, SGR, FCR, FCE, PI, \% Survival were calculated.

Growth calculations were:

Survival Rate $(\mathrm{SR})=$ number of fish stocked - number of mortalities (Paschal et al., 2006).

•\% Survival $=$

number of broodstock survivors at the end of study $\quad x 100$

number of juveniles stocked at the beginning of the study

(Coulibaly et al., 2007). 
- Specific Growth Rate \% day (SGR)

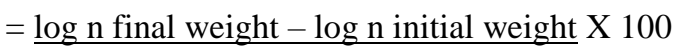

$$
\text { time (days) }
$$

(Benedict et al., 2005).

- $\mathrm{FCR}=$ Total weight of dry feed offered / Total weight gain (Sveier et al., 2000).

- FCE

$=\underline{\text { Final weight by fish }} \times 100$

Weight of feed given

(Tboujard et al., 2002).

- Performance Index

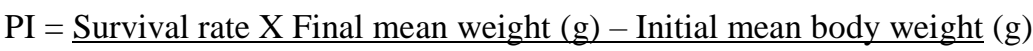

Rearing duration in days

(Engle and Valderrama, 2001).

\section{Statistical Analysis}

Data analysis were carried out using ANOVA and Duncan Multiple Range Test.

\section{Water Quality Parameters}

Water quality parameters carried out for this research were: Water Temperature, Air Temperature, DO, pH, Conductivity, Total Dissolved Solids, Alkalinity.

\section{Experimental Duration and Experimental Design}

From stocking, total sampling was carried out monthly till 121 days. Experimental design was a randomized block design.

\section{RESULTS}

Table 1 THE RESULT OF PROXIMATE ANALYSIS ON NIFFR FEED USED

\begin{tabular}{|l|l|l|l|l|l|l|l|}
\hline $\begin{array}{l}\text { FEED } \\
\text { SIZE }\end{array}$ & Treatment & $\begin{array}{l}\text { \% } \\
\text { MOISTURE } \\
\text { CONTENT }\end{array}$ & $\begin{array}{l}\text { \% ASH } \\
\text { CONTENT }\end{array}$ & $\begin{array}{l}\text { \% CRUDE } \\
\text { FIBRE }\end{array}$ & $\begin{array}{l}\text { \%CRUDE } \\
\text { PROTEIN }\end{array}$ & $\begin{array}{l}\text { \% CRUDE } \\
\text { FAT }\end{array}$ & \%NFE \\
\hline $\begin{array}{l}\text { 0.7M } \\
\text { M } \\
\text { WITH } \\
\text { OUT } \\
\text { MT }\end{array}$ & TCG 0 & $6.05 \pm 0.10^{\mathrm{a}}$ & $7.20 \pm 0.05^{\mathrm{b}}$ & $3.70 \pm 0.11^{\mathrm{a}}$ & $41.82 \pm 0.06^{\mathrm{b}}$ & $6.12 \pm 0.19^{\mathrm{a}}$ & $35.12 \pm 0.31^{\mathrm{a}}$ \\
\cline { 2 - 8 } & TCG 50 & $6.28 \pm 0.05^{\mathrm{a}}$ & $7.25 \pm 0.11^{\mathrm{b}}$ & $24.06 \pm 25.17^{\mathrm{b}}$ & $43.11 \pm 0.18^{\mathrm{b}}$ & $6.15 \pm 0.05^{\mathrm{a}}$ & $33.54 \pm 0.34^{\mathrm{a}}$ \\
\cline { 2 - 8 } & TCG 100 & $6.02 \pm 0.14^{\mathrm{a}}$ & $7.34 \pm 0.16^{\mathrm{b}}$ & $19.31 \pm 22.06^{\mathrm{b}}$ & $40.96 \pm 0.21^{\mathrm{b}}$ & $6.25 \pm 0.12^{\mathrm{a}}$ & $0.21 \pm 0.21^{\mathrm{b}}$ \\
\hline $\begin{array}{l}\text { O.7M } \\
\text { MWIT }\end{array}$ & TCG 0 & $5.84 \pm 0.08^{\mathrm{a}}$ & $7.04 \pm 0.21^{\mathrm{b}}$ & $3.57 \pm 0.12^{\mathrm{a}}$ & $40.95 \pm 0.58^{\mathrm{b}}$ & $5.93 \pm 0.25^{\mathrm{a}}$ & $36.59 \pm 0.70^{\mathrm{a}}$ \\
\cline { 2 - 8 } & TCG 50 & $5.98 \pm 0.12^{\mathrm{a}}$ & $7.41 \pm 0.21^{\mathrm{b}}$ & $3.52 \pm 0.05^{\mathrm{a}}$ & $38.58 \pm 0.22^{\mathrm{a}}$ & $5.79 \pm 0.040^{\mathrm{a}}$ & $38.72 \pm 0.54^{\mathrm{a}}$ \\
\hline
\end{tabular}




\begin{tabular}{|c|c|c|c|c|c|c|c|}
\hline & TCG 100 & $6.02 \pm 0.45^{\mathrm{a}}$ & $7.20 \pm 0.45^{b}$ & $3.66 \pm 0.03^{\mathrm{a}}$ & $39.01 \pm 0.17^{\mathrm{a}}$ & $6.31 \pm 0.59^{\mathrm{a}}$ & $37.80 \pm 0.73^{a}$ \\
\hline \multirow{3}{*}{$\begin{array}{l}\text { 2MM } \\
\text { WITH } \\
\text { OUT } \\
\text { MT }\end{array}$} & TCG 0 & $6.06 \pm 0.25^{\mathrm{a}}$ & $7.83 \pm 0.42^{\mathrm{c}}$ & $4.14 \pm 0.07^{\mathrm{a}}$ & $39.25 \pm 1.22^{\mathrm{a}}$ & $6.11 \pm 0.01^{\mathrm{a}}$ & $36.61 \pm 1.83^{a}$ \\
\hline & TCG 50 & $6.02 \pm 0.33^{\mathrm{a}}$ & $7.65 \pm 0.34^{c}$ & $4.12 \pm 0.078^{\mathrm{a}}$ & $40.22 \pm 0.53^{b}$ & $5.62 \pm 0.03^{a}$ & $36.39 \pm 0.06^{a}$ \\
\hline & TCG 100 & $6.10 \pm 0.22^{\mathrm{a}}$ & $7.75 \pm 0.24^{\mathrm{c}}$ & $4.03 \pm 0.10^{\mathrm{a}}$ & $38.87 \pm 1.17^{\mathrm{a}}$ & $5.21 \pm 0.05^{\mathrm{a}}$ & $38.04 \pm 1.76^{\mathrm{a}}$ \\
\hline \multirow{3}{*}{$\begin{array}{l}\text { 2MM } \\
\text { WITH } \\
\text { MT }\end{array}$} & TCG 0 & $6.27 \pm 0.08^{\mathrm{a}}$ & $7.25 \pm 0.10^{\mathrm{b}, \mathrm{c}}$ & $4.39 \pm 0.04^{\mathrm{a}}$ & $43.38 \pm 0.77^{b}$ & $6.27 \pm 0.056^{\mathrm{a}}$ & $32.44 \pm 0.93^{\mathrm{a}}$ \\
\hline & TCG 50 & $6.10 \pm 0.31^{\mathrm{a}}$ & $7.89 \pm 0.52^{\mathrm{c}}$ & $4.05 \pm 0.09^{\mathrm{a}}$ & $40.72 \pm 0.86^{b}$ & $6.07 \pm 0.25^{\mathrm{a}}$ & $35.17 \pm 2.02^{\mathrm{a}}$ \\
\hline & TCG 100 & $5.95 \pm 0.08^{\mathrm{a}}$ & $7.00 \pm 0.16^{\mathrm{b}, \mathrm{c}}$ & $4.21 \pm 0.03^{\mathrm{a}}$ & $42.82 \pm 0.40^{b}$ & $6.09 \pm 0.13^{\mathrm{a}}$ & $33.93 \pm 0.16^{\mathrm{a}}$ \\
\hline \multirow{3}{*}{$\begin{array}{l}\text { 4MM } \\
\text { FEED } \\
\text { WITH } \\
\text { OUT } \\
\text { MT }\end{array}$} & TCG 0 & $6.13 \pm 0.45^{\mathrm{a}}$ & $6.72 \pm 0.69^{\mathrm{a}}$ & $3.68 \pm 0.20^{\mathrm{a}}$ & $40.96 \pm 2.60^{b}$ & $6.01 \pm 1.25^{\mathrm{a}}$ & $35.30 \pm 1.56^{\mathrm{a}}$ \\
\hline & TCG 50 & $5.58 \pm 0.75^{\mathrm{a}}$ & $6.62 \pm 0.71^{\mathrm{a}}$ & $3.58 \pm 0.20^{\mathrm{a}}$ & $41.26 \pm 1.52^{b}$ & $4.69 \pm 0.79^{\mathrm{a}}$ & $31.94 \pm 0.93^{\mathrm{a}}$ \\
\hline & TCG 100 & $5.98 \pm 0.44^{\mathrm{a}}$ & $6.69 \pm 0.71^{a}$ & $3.62 \pm 0.23^{\mathrm{a}}$ & $41.46 \pm 1.64^{\mathrm{b}}$ & $5.84 \pm 0.96^{\mathrm{a}}$ & $35.32 \pm 1.25^{\mathrm{a}}$ \\
\hline \multirow{4}{*}{$\begin{array}{l}\text { 4MM } \\
\text { WITH } \\
\text { MT }\end{array}$} & TCG 0 & $6.43 \pm 0.62^{\mathrm{a}}$ & $7.14 \pm 0.35^{\mathrm{a}, \mathrm{b}}$ & $3.63 \pm 0.24^{\mathrm{a}}$ & $42.35 \pm 1.54^{b}$ & $5.23 \pm 0.11^{\mathrm{a}}$ & $32.20 \pm 1.14^{\mathrm{a}}$ \\
\hline & TCG 50 & $6.01 \pm 0.42^{\mathrm{a}}$ & $6.72 \pm 0.68^{\mathrm{a}}$ & $3.66 \pm 0.22^{\mathrm{a}}$ & $41.53 \pm 1.59^{b}$ & $5.95 \pm 0.92^{\mathrm{a}}$ & $35.45 \pm 1.34^{\mathrm{a}}$ \\
\hline & TCG 100 & $6.33 \pm 0.40^{\mathrm{a}}$ & $7.08 \pm 0.62^{\mathrm{a}, \mathrm{b}}$ & $3.78 \pm 0.22^{\mathrm{a}}$ & $41.52 \pm 2.13^{b}$ & $6.20 \pm 1.06^{\mathrm{a}}$ & $36.07 \pm 1.35^{\mathrm{a}}$ \\
\hline & STD DEV & 0.32 & 0.50 & 8.07 & 1.66 & 0.59 & 2.09 \\
\hline
\end{tabular}

Means on the same column (for each section) with different superscript are statistically significant $(\mathrm{P}<0.05)$

Table 2

GROWTH PERFORMANCE AND SURVIVAL RATE OF Clarias gariepinus JUVENILES FED FEED MIXED WITH $17 \alpha$ -METHYLTESTOSTERONE (MT) FOR ALL-MALE SEX REVERSAL AND DETERMINATION IN STAGNANT CONCRETE SYSTEMS

\begin{tabular}{|l|l|l|l|l|l|l|l|l|l|}
\hline $\begin{array}{l}\text { TAN } \\
\text { K }\end{array}$ & MIW $(\mathbf{g})$ & MFW(g) & MWG(g) & SR & \%SR & $\begin{array}{l}\text { SGR } \\
\text { (g/day) }\end{array}$ & FCR & FCE & PI \\
\hline $\begin{array}{l}\text { TCG } \\
\mathbf{0}\end{array}$ & $0.05 \pm 0.00^{\mathrm{a}}$ & $1.94 \pm 0.06^{\mathrm{a}}$ & $1.89 \pm 0.06^{\mathrm{a}}$ & $\begin{array}{l}0.92 \pm 0.02 \\
\mathrm{a}\end{array}$ & $\begin{array}{l}92.22 \pm 1.57 \\
\mathrm{a}\end{array}$ & $1.31 \pm 0.011^{\mathrm{a}}$ & $\begin{array}{l}0.12 \pm 0.00 \\
\mathrm{~b}\end{array}$ & $\begin{array}{l}8.17 \pm 0.10 \\
\mathrm{a}\end{array}$ & $\begin{array}{l}114.01 \pm 0.00 \\
\mathrm{a}\end{array}$ \\
\hline $\begin{array}{l}\text { TCG } \\
\mathbf{5 0}\end{array}$ & $0.06 \pm 0.01^{\mathrm{a}}$ & $2.45 \pm 0.21^{\mathrm{b}}$ & $2.40 \pm 0.21^{\mathrm{b}}$ & $\begin{array}{l}0.81 \pm 0.02 \\
\mathrm{a}\end{array}$ & $\begin{array}{l}81.11 \pm 1.57 \\
\mathrm{a}\end{array}$ & $1.36 \pm 0.015^{\mathrm{b}}$ & $\begin{array}{l}0.12 \pm 0.00 \\
\mathrm{a}\end{array}$ & $\begin{array}{l}8.66 \pm 0.12 \\
\mathrm{~b}\end{array}$ & $\begin{array}{l}116.02 \pm 0.00 \\
\mathrm{a}\end{array}$ \\
\hline $\begin{array}{l}\text { TCG } \\
\mathbf{1 0 0}\end{array}$ & $0.05 \pm 0.00^{\mathrm{a}}$ & $\begin{array}{l}2.05 \pm 0.07^{\mathrm{a},} \\
\mathrm{b}\end{array}$ & $\begin{array}{l}2.00 \pm 0.07^{\mathrm{a},} \\
\mathrm{b}\end{array}$ & $\begin{array}{l}0.83 \pm 0.08 \\
\mathrm{a}\end{array}$ & $\begin{array}{l}83.33 \pm 7.86 \\
\mathrm{a}\end{array}$ & $\begin{array}{l}1.33 \pm 0.012^{\mathrm{a},} \\
\mathrm{b}\end{array}$ & $\begin{array}{l}0.12 \pm 0.00 \\
\mathrm{~b}\end{array}$ & $\begin{array}{l}8.28 \pm 0.01 \\
\mathrm{a}\end{array}$ & $\begin{array}{l}114.01 \pm 0.00 \\
\mathrm{a}\end{array}$ \\
\hline
\end{tabular}

Means on the same column (for each section) with different superscript are statistically significant $(\mathrm{P}<0.05)$

Treatments: ${ }^{1}$ TCG 50 Treatment Clarias gariepinus fed $50 \mathrm{mgKg}^{-1}$ of $17 \alpha$-Methyltestosterone $\left(50 \mathrm{mgKg}^{-1} / \mathrm{MT}\right)$ in feed

${ }^{2}$ TCG 100 Treatment Clarias gariepinus fed $100 \mathrm{mgKg}^{-1}$ of $17 \alpha$-Methyltestosterone $\left(100 \mathrm{mgKg}^{-1} / \mathrm{MT}\right)$ in feed

${ }^{3}$ TCG 0 Treatment Clarias gariepinus fed $0 \mathrm{mgKg}^{-1}$ of $17 \alpha$-Methyltestosterone $\left(0 \mathrm{mgKg}^{-1} / \mathrm{MT}\right)$ in feed

MIW=Mean Initial Weight (g), MFW=Mean Final Weight $(\mathrm{g}), \mathrm{WG}=$ Weight Gain(g),SR= Survival Rate, \%SR =\% Survival Rate, SGR $=$ Specific Growth Rate, FCR=Feed Conversion Ratio, FCE=Feed Conversion Efficiency, PI = Performance Index.

Table 3a

ALL-MALE SEX REVERSAL AND VISUAL DETERMINATION OF Clarias gariepinus JUVENILES FED FEED MIXED WITH $17 \alpha$-METHYLTESTOSTERONE (MT) IN MONTH 3 


\begin{tabular}{|c|c|c|c|c|c|c|}
\hline TREATMENT & $\begin{array}{l}\text { TOTAL } \\
\text { NO OF } \\
\text { FISHES } \\
\text { (BOTH } \\
\text { SEXES) } \\
\text { IN } \\
\text { TANK }\end{array}$ & $\begin{array}{l}\text { TOTAL NO } \\
\text { OF MALES } \\
\text { AFTER } \\
\text { TREATMENT } \\
\text { WITH MT }\end{array}$ & $\begin{array}{l}\text { TOTAL NO } \\
\text { OF } \\
\text { FEMALES } \\
\text { AFTER } \\
\text { TREATMENT } \\
\text { WITH MT }\end{array}$ & $\begin{array}{lr}\text { TOTAL } & \text { NO OF } \\
\text { FISHES } & \text { WHOSE } \\
\text { SEX } & \text { ARE } \\
\text { UNDETERMINED }\end{array}$ & $\begin{array}{l}\text { PERCENTAGE } \\
\text { OF FISHES } \\
\text { SEX } \\
\text { REVERSED } \\
\text { TO ALL- } \\
\text { MALE }(\%)\end{array}$ & $\begin{array}{l}\text { PERCENTAGE } \\
\text { OF FISHES } \\
\text { REMAINING } \\
\text { AS FEMALES } \\
(\%)\end{array}$ \\
\hline TCG 50 $^{1}$ & 36 & 26 & 10 & - & 72.22 & 27.78 \\
\hline TCG $50^{2}$ & 37 & 28 & 8 & 1 & 77.77 & 21.62 \\
\hline TCG $100^{1}$ & 35 & 30 & 5 & - & 85.71 & 14.29 \\
\hline TCG $100^{2}$ & 40 & 28 & 11 & 1 & 70.00 & 27.50 \\
\hline TCG 0 $^{1}$ & 41 & 1 & 40 & - & 2.43 & 97.56 \\
\hline TCG $0^{2}$ & 42 & 2 & 40 & - & 4.76 & 95.24 \\
\hline
\end{tabular}

Table 3b

ALL-MALE SEX REVERSAL AND VISUAL DETERMINATION OF Clarias gariepinus JUVENILES FED FEED MIXED WITH $17 \alpha$-METHYLTESTOSTERONE (MT) IN MONTH 4

\begin{tabular}{|c|c|c|c|c|c|c|}
\hline TREATMENT & $\begin{array}{l}\text { TOTAL } \\
\text { NO OF } \\
\text { FISHES } \\
\text { (BOTH } \\
\text { SEXES) } \\
\text { IN } \\
\text { TANK } \\
\end{array}$ & $\begin{array}{l}\text { TOTAL NO } \\
\text { OF MALES } \\
\text { AFTER } \\
\text { TREATMENT } \\
\text { WITH MT }\end{array}$ & $\begin{array}{l}\text { TOTAL NO } \\
\text { OF } \\
\text { FEMALES } \\
\text { AFTER } \\
\text { TREATMENT } \\
\text { WITH MT }\end{array}$ & $\begin{array}{lrr}\text { TOTAL } & \text { NO OF } \\
\text { FISHES } & \text { WHOSE } \\
\text { SEX } & \text { ARE } \\
\text { UNDETERMINED }\end{array}$ & $\begin{array}{l}\text { PERCENTAGE } \\
\text { OF FISHES } \\
\text { SEX } \\
\text { REVERSED } \\
\text { TO ALL- } \\
\text { MALE }(\%)\end{array}$ & $\begin{array}{l}\text { PERCENTAGE } \\
\text { OF FISHES } \\
\text { REMAINING } \\
\text { AS FEMALES } \\
(\%)\end{array}$ \\
\hline TCG 50 ${ }^{1}$ & 36 & 26 & 10 & - & 72.22 & 27.78 \\
\hline TCG $50^{2}$ & 37 & 29 & 8 & - & 78.38 & 24.32 \\
\hline TCG $100^{1}$ & 35 & 30 & 5 & - & 85.71 & 14.29 \\
\hline TCG 100 ${ }^{2}$ & 40 & 29 & 11 & - & 72.50 & 27.50 \\
\hline TCG $0^{1}$ & 41 & 1 & 40 & - & 2.43 & 97.56 \\
\hline${\text { TCG } 0^{2}}^{2}$ & 42 & 2 & 40 & - & 4.76 & 95.24 \\
\hline
\end{tabular}

Table 4

MORPHOMETRIC MEASUREMENTS AND CONDITION FACTOR OF Clarias gariepinus JUVENILES FED FEED MIXED WITH $17 \alpha$-METHYLTESTOSTERONE (MT) FOR ALL-MALE SEX REVERSAL AND DETERMINATION IN CONCRETE STAGNANT SYSTEMS

\begin{tabular}{|l|l|l|l|l|l|l|l|l|}
\hline Treatments & $\begin{array}{l}\text { Total } \\
\text { Length } \\
(\mathbf{c m})\end{array}$ & $\begin{array}{l}\text { Standard } \\
\text { length }(\mathbf{c m})\end{array}$ & $\begin{array}{l}\text { Weight gain } \\
(\mathbf{g})\end{array}$ & $\begin{array}{l}\text { Condition } \\
\text { factor }(\mathbf{K})\end{array}$ & $\begin{array}{l}\text { Minimum } \\
\text { values } \\
(\mathbf{T L})\end{array}$ & $\begin{array}{l}\text { Maximum } \\
\text { values (TL) }\end{array}$ & $\begin{array}{l}\text { Minimum } \\
\text { values } \\
(\mathbf{S L})\end{array}$ & $\begin{array}{l}\text { Maximum } \\
\text { values }(\mathbf{S L})\end{array}$ \\
\hline TCG 0 & $8.95 \pm 6.46^{\mathrm{b}}$ & $7.44 \pm 6.13^{\mathrm{a}}$ & $1.89 \pm 0.06^{\mathrm{a}}$ & $6.10 \pm 3.41^{\mathrm{a}}$ & 1.2 & 22.4 & 1.1 & 21.8 \\
\hline TCG 50 & $9.49 \pm 6.76^{\mathrm{a}}$ & $8.51 \pm 6.45^{\mathrm{b}}$ & $2.40 \pm 0.21^{\mathrm{b}}$ & $6.68 \pm 4.13^{\mathrm{a}}$ & 1.0 & 25.5 & 4.5 & 24.8 \\
\hline TCG 100 & $9.44 \pm 6.18^{\mathrm{a}}$ & $8.11 \pm 5.30^{\mathrm{b}}$ & $2.00 \pm 0.07^{\mathrm{a}, \mathrm{b}}$ & $5.99 \pm 3.83^{\mathrm{a}}$ & 0.8 & 20.5 & 4.2 & 20.9 \\
\hline
\end{tabular}

Means on the same column (for each section) with different superscript are statistically significant $(\mathrm{P}<0.05)$ 


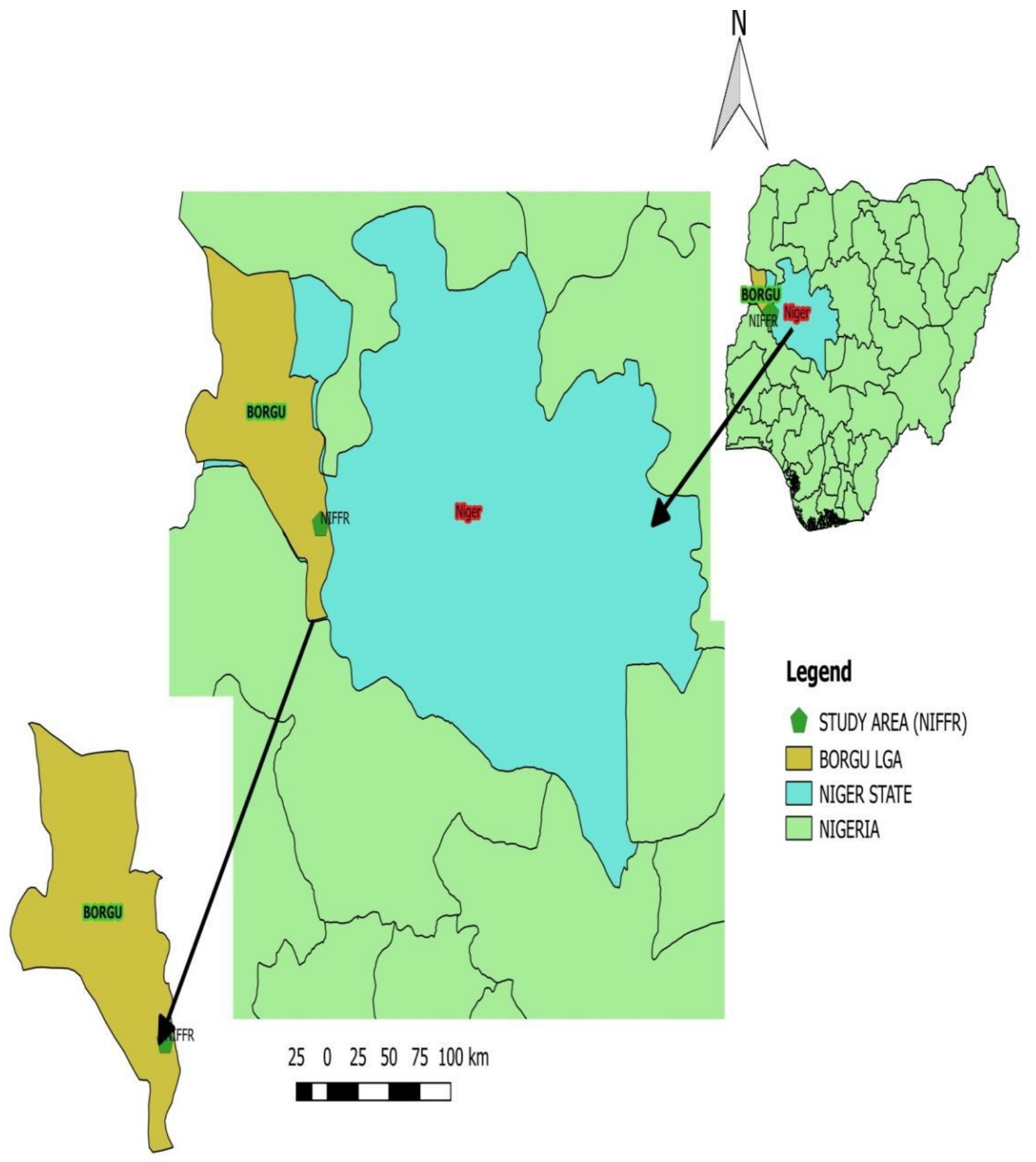

Source: NIFFR Archives, (2015) and Robert et al., (2019a)

Figure I: Map of Borgu Local Government Area with headquarters at New Bussa 


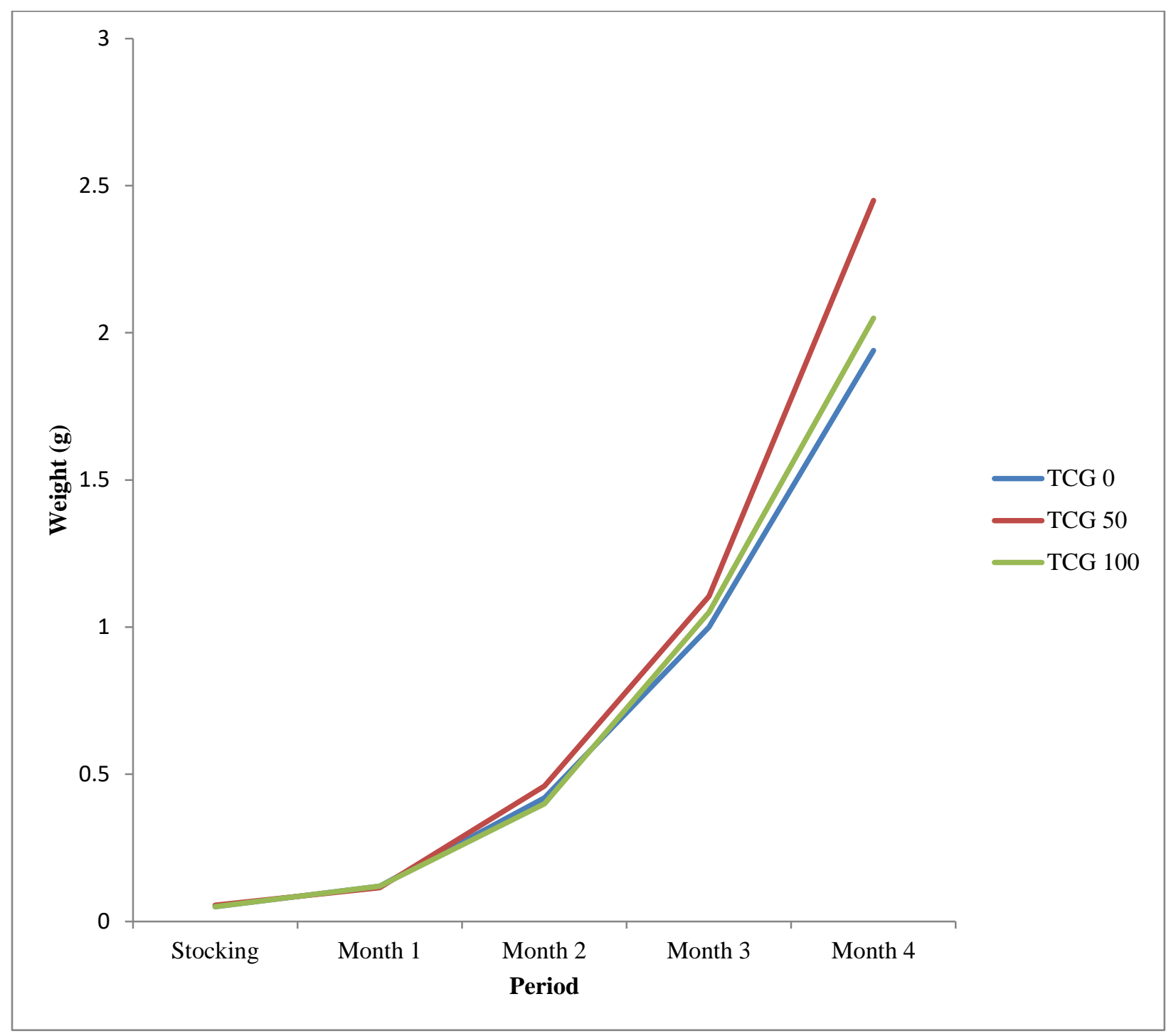

Figure 2: Growth patterns of Clarias gariepinus juveniles fed feed mixed with $17 \alpha$-Methyltestosterone (MT) in varying doses for all-male sex reversal and determination in stagnant concrete systems

Table 5

LENGTH-WEIGHT RELATIONSHIP REGRESSION OF Clarias gariepinus JUVENILES FED FEED MIXED WITH $17 \alpha$ -METHYLTESTOSTERONE (MT) FOR ALL-MALE SEX REVERSAL AND DETERMINATION IN CONCRETE STAGNANT SYSTEMS

\begin{tabular}{|c|c|c|c|}
\hline & Intercept & Growth pattern & Coefficient of determination \\
Treatments & $(\mathbf{a})$ & $(\mathbf{b})$ & $\left(\mathbf{R}^{2}\right)$ \\
\hline TCG 0 & 1.37 & 1.60 & 0.80 \\
\hline
\end{tabular}

www.scirj.org

(C) 2019, Scientific Research Journal

http://dx.doi.org/10.31364/SCIRJ/v7.i8.2019.P0819691 


\begin{tabular}{|c|c|c|c|}
\hline TCG 50 & 1.45 & 1.64 & 0.84 \\
\hline TCG 100 & 1.41 & 1.62 & 0.82 \\
\hline
\end{tabular}

TABLE 6

\begin{abstract}
WATER QUALITY PARAMETERS OF Clarias gariepinus JUVENILES FED FEED MIXED WITH $17 \alpha-$ METHYLTESTOSTERONE (MT) FOR ALL-MALE SEX REVERSAL AND DETERMINATION IN CONCRETE STAGNANT SYSTEMS
\end{abstract}

\begin{tabular}{|c|c|c|c|c|c|c|c|}
\hline Treatments & $\begin{array}{c}\text { Water } \\
\text { Temp }\left({ }^{\circ} \mathbf{c}\right)\end{array}$ & $\begin{array}{c}\text { Air Temp } \\
\left({ }^{\circ} \mathbf{c}\right)\end{array}$ & pH & DO (mg/l) & $\begin{array}{l}\text { Conduct } \\
(\mu \mathrm{S} / \mathrm{cm})\end{array}$ & TDS (mg/l) & Alk (mg/l) \\
\hline TCG 0 & $26.33 \pm 3.83^{\mathrm{a}}$ & $31.17 \pm 3.36^{\mathrm{a}}$ & $7.58 \pm 0.58^{\mathrm{a}}$ & $6.23 \pm 1.40^{\mathrm{a}}$ & $49.33 \pm 18.67^{\mathrm{a}}$ & $23.42 \pm 12.27^{\mathrm{a}}$ & $18.17 \pm 3.25^{b}$ \\
\hline TCG 50 & $26.33 \pm 3.78^{a}$ & $30.47 \pm 3.97^{\mathrm{a}}$ & $7.53 \pm 0.48^{\mathrm{a}}$ & $5.92 \pm 1.10^{\mathrm{a}}$ & $50.17 \pm 21.04^{\mathrm{a}}$ & $22.49 \pm 10.97^{\mathrm{a}}$ & $16.33 \pm 4.60^{b}$ \\
\hline TCG 100 & $27.29 \pm 3.72^{b}$ & $30.2 \pm 4.37^{\mathrm{a}}$ & $7.62 \pm 0.53^{\mathrm{a}}$ & $5.93 \pm 0.72^{\mathrm{a}}$ & $68.67 \pm 15.32^{b}$ & $31.48 \pm 4.88^{b}$ & $15.17 \pm 4.31^{\mathrm{a}}$ \\
\hline
\end{tabular}

Means on the same column (for each section) with different superscript are statistically significant $(\mathrm{P}<0.05)$

\title{
DISCUSSION
}

Growth performance of Clarias gariepinus juveniles fed feed mixed with $17 \alpha$-methyltestosterone (MT) for all-male sex reversal and determination in concrete stagnant systems

Initial weights of Clarias gariepinus fry ranged from $0.05 \mathrm{~g}$ to $0.06 \mathrm{~g}$ as seen on Table 2. Previous studies have shown that fish fed without MT do not show improved growth (Mocintosh et al.,1985, Marjani et al., 2009 and Robert et al., 2019b) as also seen in this study; there was no significant difference in mean initial weights (MIW) among the treatments. The lowest mean final weight was observed in the treatment TCG 0 . There were 39 mortalities from stocking till end of the experiment. These mortalities were due to weather changes. As a measure, total sampling and fresh water added to the tanks every sampling day was carried out to stop further mortalities. Highest mean weight were observed in the tanks with treatment TCG 50. It is therefore suggested that weights were similar in the tanks treated with MT (TCG 50, TCG 100) than in the tanks not treated with MT (TCG 0) and there was no significant difference between TCG 50 and TCG 100 but, there was a significant difference between TCG 0 and TCG 50. Robert et al., (2019b) reported final weight for Clarias gariepinus broodstocks fed with MT in concentrations of $50 \mathrm{mgKg}^{-1} / \mathrm{MT}$ (TC 50) in a previous study carried out for 90 days as $3.47 \mathrm{~g}$ and $2.30 \mathrm{~g}$ for $100 \mathrm{mgKg}^{-1} / \mathrm{MT}$ (TC 100). There was a significant difference in that study between treatments TC 50 and TC 100.

Percentage weight gain (\%WG) for this study on all-male sex reversal showed also on Table 2 that, the highest weight gain for Clarias gariepinus juveniles was seen in treatment tanks TCG 50. This could be due to the excellent feed utilization abilities of the specie. This study further postulates that Clarias gariepinus juveniles show higher growth rate when fed feed mixed with MT. A previous study by Robert et al., (2019b) on growth, survival and reproductive success of Clarias gariepinus broodstocks fed with MT suggested $(\% \mathrm{WG})$ of 55.15 , higher than the $(\% \mathrm{WG})$ in this study. There was a significant difference in the weight gain between treatments TC 50 and TC 0, but there was no significant difference in the weight gain between treatments TC 100 and TC 50. 
The Specific growth rate (SGR\%) on all-male sex reversal observed in this study showed highest values for TCG 50. This showed that the fish responded very well to the feed taken, much more than other treatments. However, values for SGR in this study were much higher than values for SGR in previous studies conducted by Robert et al., (2019b) and Mubarik et al., (2011). There was a significant difference between treatments TCG 0 and TCG 50; but no significant difference between treatments TCG 50 and TCG 100 .

Percentage survival (\% survival) values recorded in this study on all-male sex reversal were highest in treatment TCG 0 . Robert et al., (2019b) in a similar study reported however, highest (\% survival) as 87.50; quite lower than the (\% survival) values in this study. There was no significant difference among the treatments attesting to Clarias gariepinus' ability to survive under any culture medium (Viveen et al.,1985).

Food conversion ratio (FCR) also seen on Table 2 suggests higher FCR and a non-significant difference between treatment TCG 0 and TCG 100; but a significant difference between treatment TCG 50 and TCG 100, TCG 50 and TCG 0, postulating therefore that, Clarias gariepinus juveniles used less feed to gain more weight. These values are similar to the FCR values reported in a previous study conducted by Robert et al.,(2019b). However, the FCR values in this study show that food conversion was excellent than in a similar study conducted by Mubarik et al.,(2011) which reported very low FCR values of 0.020 and 0.009 for T 50 and T 100 tanks, which were fed with $50 \mathrm{mgKg}^{-1} / \mathrm{MT}$ and $100 \mathrm{mgKg}^{-1} / \mathrm{MT}$ respectively.

Feed conversion efficiency (FCE), are often a visible reflection of FCR values (Ndome et al., 2011 and Robert et al., 2019a). FCE values in this study are higher than FCE values in a similar study reported by (Robert et al.,2019b). There was a significant difference between treatment TCG 0 and TCG 50, TCG 50 and TCG 100, but no significant difference between treatment TCG 0 and TCG 100 .

Performance Index (PI) for a similar, previous study on MT by Robert et al., (2019b) reported values as high as 601.85 and as low as 458.33. The performance index values in this study corroborate that of Robert et al., (2019b), depicting no significant difference among the treatments, yet supporting (Viveen et al., 1985) that Clarias gariepinus can thrive under favorable or harsh culture conditions.

Sex reversal performance by visual determination of Clarias gariepinus juveniles fed feed mixed with $17 \alpha$-methyltestosterone (MT) in concrete stagnant systems

On tables $3 \mathrm{a}$ and $3 \mathrm{~b}$, the percentage of males in the fish tanks after sex reversal and visual determination indicated values as low as $2.43 \%$ and $4.76 \%$ for Clarias gariepinus juveniles in treatment TCG 0, fed without MT; and higher values of $85.71 \%$ and $72.50 \%$, $78.38 \%$ and $72.22 \%$ for treatments TCG 100 and TCG 50 respectively, fed with MT in their feed.

Morphometric measurements and Condition factor of Clarias gariepinus juveniles fed feed mixed with $17 \alpha-$ methyltestosterone (MT) for all-male sex reversal and determination in concrete stagnant systems

The morphometric measurements and condition factor of Clarias gariepinus juveniles as seen on Table 4 clearly depict minimum and maximum total lengths for treatment TCG 0 as ranging from $1.2 \mathrm{~cm}$ to $22.4 \mathrm{~cm}, 1.0 \mathrm{~cm}$ to $25.5 \mathrm{~cm}$ for treatment TCG 50 and $0.8 \mathrm{~cm}$ to $20.5 \mathrm{~cm}$ for treatment TCG 100 .

Minimum and maximum standard lengths for treatment TCG 0 ranged from $1.1 \mathrm{~cm}$ to $21.8 \mathrm{~cm}, 4.5 \mathrm{~cm}$ to $24.8 \mathrm{~cm}$ for treatment TCG 50 and $4.2 \mathrm{~cm}$ to $20.9 \mathrm{~cm}$ for treatment TCG 100 . Weight gain values ranged from $1.89 \mathrm{~g}$ to $2.40 \mathrm{~g}$ throughout the treatment; with highest weight gain recorded for treatment TCG 50 being $2.40 \mathrm{~g}$ in the study. Robert et al., (2019b) reported higher weight gain values in a similar study involving the use of MT. Condition factor (K) in this study showed greater than 1 values, establishing that the fishes were healthy. Robert et al., (2019b) reported Condition factor values ranging from 3.13 to 7.20 ; those values are similar with the Condition factor values in this study. Condition factor showed no significant difference among treatments in this study.

Growth patterns of Clarias gariepinus juveniles fed feed mixed with $17 \alpha$-methyltestosterone (MT) for all-male sex reversal and determination in concrete stagnant systems

According to Khairenizam and Norma-Rashid, (2002); Robert et al., (2019a), when the b-value is less than 3, the fish is reported to have grown negatively allometric. When the b-value is more than 3 , the fish has grown positively allometric but when the b-value is equal to 3 , the fish is reported to have grown isometrically.

www.scirj.org

(C) 2019, Scientific Research Journal

http://dx.doi.org/10.31364/SCIRJ/v7.i8.2019.P0819691 
The b-values in this study showed negative allometry for all treatments indicative of the fact that the fishes grew more in length than they grew in weight (Anderson and Neumann, 1996). Pauly, (1983) stated that the degree of fatness of a fish is linked directly to the fish' condition factor, which is often due to seasonal factor, as the highest weight in fish is normally seen during the peak of the rainy season. This study was conducted in the dry season and thus further explains the negative allometric condition of the fishes.

The growth patterns shown in figure 2 for treatments TCG 50 highlights the fastest growth among the treatments from stocking till end of experiment. A greater weight increase was clearly seen throughout the duration of the study. Treatment TCG 100 showed very fast growth patterns from stocking till end of experiment. Weight increase was fast but not as fast as it was seen in the fishes under treatment TCG 50. Treatment TCG 0 on the other hand, grew slowly yet progressively from stocking till end of experiment. Weight increase was slow too.

\section{Length-weight relationship regression of Clarias gariepinus juveniles fed feed mixed with $17 \alpha$-methyltestosterone (MT) for all-male sex reversal and determination in concrete stagnant systems}

Coefficient of determination results from this study highlighted regression values for treatment TCG 0 as 0.80 , treatment TCG 50 as 0.84 and treatment TCG 100 as 0.82 . All of these values indicated strong values for regression in the study.

Strong regression $\left(\mathrm{R}^{2}\right)$ values should be from 0.5 and more (Davies et al., 2013; Robert et al., 2019a). Robert et al., (2019b) reported in a similar study on MT, stronger regression values of 0.61 to 1.98 .

\section{Water quality parameters of Clarias gariepinus juveniles fed feed mixed with $17 \alpha$-methyltestosterone (MT) for all-male sex reversal and determination in concrete stagnant systems}

The water quality parameters in this study have shown almost similar temperature values. Water temperature values in this study ranged from $26.33 \pm 3.83^{\mathrm{a}}$ to $27.29 \pm 3.72^{\mathrm{b}}$, indicative of being within range for freshwater culture as stated by Chakroff (1976) and Robert et al., (2019a) who reported optimal water temperature range as $25^{\circ} \mathrm{C}$ to $31.36^{\circ} \mathrm{C}$. High water temperatures have however, been reported to range from $23^{\circ} \mathrm{c}$ to $25^{\circ} \mathrm{C}$. (Lee and Rinne, 1980; Bjorn and Reiser, 1991; Hodgson and Quinn, 2002). This report does not agree with the water temperature values in this study. However, the water temperature values in this study agree with the report of Robert et al., (2019a). There was a significant difference in water temperature between treatment TCG 50 and TCG 100 but no significant difference between treatment TCG O and TCG 50.

Air Temperature values in this study stood between $30.20 \pm 4.37^{\mathrm{a}}$ to $31.17 \pm 3.36^{\mathrm{a}}$; also showing similar values throughout the treatments. There was no significant difference in the air temperature values throughout the treatments.

$\mathrm{pH}$ values in the study showed values from $7.53 \pm 0.48^{\mathrm{a}}$ to $7.62 \pm 0.53^{\mathrm{a}}$. These values were similar throughout the treatments. There was no significant difference in $\mathrm{pH}$ values among the treatments. Boyd and Lichtkoppler (1979) stated that the ideal $\mathrm{pH}$ range is from 6.7 to 8.6. Robert et al., (2019a) also postulated pH range of 7.16 to 8.20 in their study on monosex culture of Heterobranchus longifilis juveniles.

DO values in this study ranged from $5.92 \pm 1.10^{\mathrm{a}}$ to $6.23 \pm 1.40^{\mathrm{a}}$ throughout the treatments. These values were within range for freshwater fish culture as reported by Ovie and Adeniji (1990), who said that fish do not grow well when dissolved oxygen remains at 4mg/l. Again, Robert et al., (2019a) also stated in an earlier study that at $4.40 \mathrm{mg} / \mathrm{l}$, fish deaths were not seen. There was no significant difference in the DO results of this study among the treatments.

Conductivity values in this study ranged from $49.33 \pm 18.67^{\mathrm{a}} \mu \mathrm{S} / \mathrm{cm}$ to $68.67 \pm 15.32^{\mathrm{b}} \mu \mathrm{S} / \mathrm{cm}$ throughout the treatments. These values were lower than values reported to be within range for freshwater fish culture as stated by Boyd, (1990) and Robert et al., (2019a). Both stated freshwater conductivity ranges were from $212 \mu \mathrm{S} / \mathrm{cm}$ to $436 \mu \mathrm{S} / \mathrm{cm}$. Ayanwale et al., (2012) further reported conductivity ranges of 100.60 to $338.00 \mu \mathrm{S} / \mathrm{cm}$ for artificial fish culture. Lower conductivity values are deemed a function of the bedrock material on which a pond is sited (Russell et al., 2011); human activities force higher conductivity levels of $100 \mu \mathrm{S} / \mathrm{cm}$ (Crane, 2006). There was no significant difference between treatment TCG 0 and TCG 50 but, there was a significant difference between treatment TCG 50 and TCG 100. 
Total Dissolved Solids values in this study ranged from $22.49 \pm 10.97^{\mathrm{a}}$ to $31.48 \pm 4.88^{\mathrm{b}}$ throughout the treatments. Water containing Total Dissolved Solids less than $1000 \mathrm{mgL}^{-1}$ is called "Fresh Water" and considered good enough for irrigation and drinking purposes (Freeze and Cherry, 1979, Shahidullah et al., 2000 and Oyem et al.,2014). There was no significant difference between treatment TCG 0 and TCG 50. However, there was a significant difference between treatment TCG 50 and TCG 100.

Alkalinity values in this study stood between $15.17 \pm 4.31^{\mathrm{a}}$ to $18.17 \pm 3.25^{\mathrm{b}}$ throughout the treatments. For the safety and protection of aquatic life, alkalinity should be at least $20 \mathrm{mg} / \mathrm{L}$. (Oyem et al.,2014). There was no significant difference between treatment TCG 0 and TCG 50. However, there was a significant difference between treatment TCG 50 and TCG 100.

\section{REFERENCES}

Anderson, R.O. \& Neumann, R.M. (1996). Length, weight and associated structural indices in Fisheries Techniques. $2^{\text {nd }}$ Edition. In B.E. Murphy and D.W. Willis (Eds.) American Fisheries Society 1996.

Ayanwale, A.V., Minnin, M.A. \& Olayemi, K.I. (2012). Physico-chemical properties of selected fish ponds in Nigeria. Implications for artificial fish culture. Webmed Central Biology, 3(10): WMC003751.

Benedict, O.O., Gabriel, U.I. \& Ezekiel, O.A. (2005). Effect of stocking size of the predatory African Catfish (Heterobranchus longifilis V.) on the growth performance of Nile Tilapia (Oreochromis niloticus L.) in pond culture. International Journal of Fisheries and Aquaculture. 1(3):38-43.

Bjorn, T.C. \& Reiser, D.W.(1991). Habitat requirements of Salmonids in streams. In: Influences of forest and rangeland management on Salmonid fishes and their habitats. American Fisheries Society, Bethesda, MD. Special publication 19: 83-158.

Boyd, C.E. (1990a). Water quality in ponds for aquaculture. Alabama Agricultural Experiment Station, Auburn University, Auburn, Alabama. In T. B. Lawson(1994). Fundamentals of Aquacultural Engineering. pp. 18-19.

Boyd, C.E. \& Lichtkoppler, F. (1979). Water quality management in pond fish culture. International Centre for Aquaculture Agricultural Experiment Station, Auburn University, Auburn, Alabama. Research and Development series No 22. Project: AID/DSAN-G 0039.

Charkroff, M. (1976). Freshwater Fish Pond Culture and Management,Action /Peace Corps Programme and Training Journal, manual series number 1B. Volunteers in Technical Assistance (VITA). Publications manual series number 36E.

Coulibaly, A., Ouattara, I. N., Kone, T., N’Douba, V., Snoeks, J., Goore Bi, G. \& Kouamelan, E. P. (2007). First results of floating cage culture of the African Catfish Heterobranchus longifilis. Valenciennes, 1840: Effect of stocking density on survival and growth rates. Universite de Cocody-Abidjan. Journal of Aquaculture. 263: 61-67.

Crane,B. (2006). Results of Water Quality Measurements in Messer Pond. http://www.messerpond.org/Ecology/WaterSamplingSummary.pdf. Accessed 23 August 2017. 
Davies, O.A., Tawari, C.C. \& Kwen, K. (2013). Length-Weight Relationship ,Condition factor and Sex ratio of Clarias gariepinus juveniles reared in concrete tanks. International Journal of Scientific Research in Environmental Studies (IJSRES), 1(11), pp. 324-329.

Engle, C.R. \& Valderrama, D. (2001). Effect of stocking density on production characteristics, coasts and risk of producing fingerlings channel catfish. North American Journal of Aquaculture, 63: 201-207.

Freeze, R.A. \& Cherry, J.A. (1979). Groundwater. (2 ${ }^{\text {nd }}$ eds.) Prentice Hall Inc., Englewood, NJ., USA., ISBN-13: 9780133653120, pp.604. In: Oyem, H.H., Oyem, I.M. \& Ezeweali, D. (2014). Temperature, pH, Electrical Conductivity, Total Dissolved Solids and Chemical Oxygen Demand of Groundwater in Boji-BojiAgbor/ Owa Area and Immediate Suburbs. 8(8): 444-450.

Hodgson, S. \& Quinn, T. (2002). The timing of adult sockeye salmon migration into fresh water: adaptations by populations to prevailing thermal regimes. Canadian Journal of Zoology,80(3): 542-555.

Hoga, C.A., Almeida, F.L. \& Reyes, F.G.R. (2018). A review on the use of hormones in fish farming: Analytical methods to determine their residues. CYTA Journal of Food, 16 (1): 679-691.

Khairenizam, M.Z. \& Norma - Rashid, Y. (2002). Length - Weight relationship of mudskippers ( Gobidae: Oxudercinae) in the coastal areas of Sclangor, Malaysia International Centre for living Aquatic Resources Management, World Fish Centre Quarterly, 25: 20-22.

Lee, R.M. \& Rinne, J.N. (1980). Critical thermal maxima of five trout species in the Southwestern United States. Transactions of the American Fisheries Society 209(6): 632-635.

Macintosh, D. J., Varghese, T.J. \& Rao Satyanarayana, G.P. (1985). Rao hormonal sex reversal of wild spawned tilapia in India. Journal of Fish Biology, 28: 87-94. In: Marjani, M., Jamili, P.G., Mostafavi, M., Ramin, M. \& Maschinchian, A. (2009). Influence of 17- $\alpha$-Methyl Testosterone on Masculinization and Growth in Tilapia (Oreochromis mossambicus). Journal of Fisheries and Aquatic Science, 4: 71-74.

Marjani, M., Jamili, P.G., Mostafavi, M., Ramin, M. \& Maschinchian, A. (2009). Influence of 17- $\alpha$-Methyl Testosterone on Masculinization and Growth in Tilapia (Oreochromis mossambicus). Journal of Fisheries and Aquatic Science, 4: 7174.

Megbowon, I., Fashina-Bombata, H.A.,Mojekwu, T.O. \& Okuade, O.A. (2009). Genetic improvement of tilapia: Challenges and prospects in Nigeria. Nigerian Journal of Fisheries, 6: 21-30.

Megbowon,I. \& Mojekwu, T.O. (2014). Tilapia Sex Reversal Using Methyl Testosterone (MT) and its Effect on Fish, Man and Environment. Biotechnology, 13:213-216.

Mubarik,, M.S., Ahmed, I., Mateen, A. \& Iqbal, Tahira (2011). 17- $\alpha$-Methyl Testosterone Induced Masculinization and its Effect on Growth and Meat Quality of Cyprinus carpio. International Journal of Agriculture and Biology, 13: $971-975$.

Www.scirj.org 
NIFFR (2015). National Institute for Freshwater Fisheries Research (NIFFR) Archives, with researcher's modification. 2017-10-20.

Ndome, C.B., Ekwu, A.O. \& Ateb, A.A. (2011). Effect of Feeding Frequency on Feed Consumption, Growth and Feed Conversion of Clarias gariepinus Male and Heterobranchus longifilis Female Hybrids in Glass Aquaria. American-Eurasian Journal of Scientific Research 6 (1):06-12-2011.

Oyem, H.H., Oyem, I.M. \& Ezeweali, D. (2014). Temperature, pH, Electrical Conductivity, Total Dissolved Solids and Chemical Oxygen Demand of Groundwater in Boji-BojiAgbor/ Owa Area and Immediate Suburbs, 8(8): 444-450.

Pandian, T.J. \& Sheela, S.G. (1995).Review: Hormonal induction of sex reversal in fish. Aquaculture, 138: 1-22

Piferrer, F. (2001). Endocrine sex control strategies for the feminization of teleost fish. Aquaculture. 197: 229-281.

Robert, E.A., Yisa, A.T. \& Tsadu, S.M. (2019a). Growth performance and survival of monosex cultured Heterobranchus longifilis juveniles in concrete flow-through and stagnant water systems. Scientific Research Journal (SCIRJ), 7(2): 43-65. DOI: $10.31364 /$ SCIRJ/v7.i2.2019.P0219615.

Robert, E.A., Onyeche, V.O., Ovie, S.O., Biyontubo, O., Ekundayo, T. \& Offor, C.C. (2019b). Growth, survival and reproductive success of Clarias gariepinus broodstocks fed feed mixed with 17- $\alpha$-MethylTestosterone (MT) in stagnant concrete systems. Scientific Research Journal (SCIRJ), 7(3): 17-32. DOI: 10.31364/SCIRJ/v7.i3.2019.P0319620.

Russell, M., Shuke, R. \& Samantha, S. (2011). Effects of Conductivity on Survivorship and Weight of Goldfish (Carassius auratus). http://departments.juniata.edu/biology/eco/documents/Russell_et al.pdf. Accessed 23 April 2017.

Shahidullah, S.M., Hakim, M.A., Alam, M.S. \& Shamsuddoha, A.T.M. (2000). Assessment of groundwater quality in a selected area of Bangladesh. Pakistani Journal of Biological Science. 3:246-249. In: Oyem, H.H., Oyem, I.M. \& Ezeweali, D. (2014). Temperature, pH, Electrical Conductivity, Total Dissolved Solids and Chemical Oxygen Demand of Groundwater in Boji-BojiAgbor/ Owa Area and Immediate Suburbs, 8(8): 444-450.

Sveier, H., Raae, A.J. \& Lied, E. (2000). Growth and protein turnover in Atlantic salmon (Salmo salar L.); the effect of dietary protein level and protein particle size. Aquaculture, 185: 101-120.

TBoujard, L., Labbe, L., \& Auperin, B. (2002). Feeding behavior , energy expenditure and growth of rainbow trout in relation to stocking density and food accessibility. Aquaculture Research, 33: 1233-1242.

Viveen, W.J.A.R., Richter, C.J.J., Van Oordt, P.E.W.G., Janssen, J.A.L. \& Huisman, E.A. (1985). Practical Manual for the culture of the African Catfish (Clarias gariepinus). Directorate General for International Technical Corporation. The Hague, pp. 93. 
